\title{
PENGEMBANGAN MODEL EVALUASI PENYELENGGARAAN SEKOLAH ISLAM TERPADU
}

\author{
Retno Wabyuningsib, Budiyono \\ Institut Agama Islam Negeri Surakarta, Universitas Sebelas Maret Surakarta \\ retnowahyuningsih2008@gmail.com,bud@uns.ac.id
}

\begin{abstract}
Abstrak
Penelitian ini bertujuan untuk: (1) mengembangkan model evaluasi yang tepat sehingga dapat digunakan untuk mengevaluasi penyelenggaraan SDIT, (2) mendeskripsikan karakteristik instrumen dalam model evaluasi SIT, (3) mendeskripsikan efektivitas model evaluasi SIT, dan (4) mengetahui gambaran dan kriteria hasil evaluasi yang dilaksanakan di SDIT. Studi ini merupakan penelitian pengembangan, yang terdiri dari sembilan tahap kegiatan, yaitu: pengumpulan informasi, perencanaan, pengembangan produk awal, penilaian pakar, revisi produk utama, pengujian lapangan utama, revisi produk operasional, pengujian lapangan operasional, dan revisi produk akhir. Kesimpulan penelitian ini adalah: (1) telah dihasilkan model evaluasi penyelenggaraan sekolah Islam terpadu (EPSIT); (2) karakteristik instrumen dalam model EPSIT: a. memiliki format sangat baik, b. memenuhi substansi model evaluasi, c. memiliki validitas konstruk yang dapat diandalkan, d memiliki reliabilitas yang tinggi, (3) Model EPSIT memiliki keefektifan sangat baik dan memenuhi standar untuk mengevaluasi penyelenggaraan SDIT; (4) kriteria dalam Model EPSIT dapat memberikan gambaran secara menyeluruh penyelenggaraan SDIT.
\end{abstract}

Kata kunci: model evaluasi, penyelenggaraan, sekolah Islam terpadu

\section{DEVELOPING AN EVALUATION MODEL FOR THE IMPLEMENTATION OF INTEGRATED ISLAMIC SCHOOLS}

\author{
Retno Wahyuningsih, Budiyono \\ Institut Agama Islam Negeri Surakarta, Universitas Sebelas Maret Surakarta \\ retnowahyuningsih2008@gmail.com,bud@uns.ac.id
}

\begin{abstract}
This study aims at (1) developing an appropriate evaluation model as a means of evaluating the implementation of Integrated Islamic Primary School, (2) describinge the characteristic of instrument of SIT evaluation model (3) describinge the effectiveness of the developed SIT model of evaluation, and (4) knowing the description and the criteria of evaluation results implemented at SDIT. This is a research and development study which comprises nine steps:collecting information, planning, developing preliminary product, experts' judgments, revising the main product, main field testing, revising the operational product, operational field testing, and final product revision. The conclusions are as follows: (1) An evaluation model was developed for the integrated Islamic school (EPSIT); (2) The characteristics of the instrument in the EPSIT model are : a. having excellent format, $b$. havinge met the substance of evaluation model, c. having a good validity construct, and d. having a high level reliability; (3) The EPSIT model is very effective and meets the standard to evaluate the implementation of SDIT; (4) the criteria under the EPSIT model can give thorough description of the implementation of the SDIT.
\end{abstract}

Keywords: evaluation model, implementation, integrated Islamic schools 


\section{Pendahuluan}

Globalisasi yang telah melanda kehidupan manusia menyebabkan bangsa Indonesia yang mayoritas penduduknya muslim harus menghadapi segala implikasinya. Selain mendatangkan sejumlah kemudahan bagi manusia, globalisasi juga mendatangkan sejumlah efek negatif yang dapat merugikan dan dapat mengancam kehidupan. Dampak negatif globalisasi menjelma dalam bentuk degradasi moral yang melanda bangsa Indonesia di berbagai segmen kehidupan masyarakat, tak terkecuali generasi muda. Oleh karena itu, perlu upaya peningkatan kualitas sumber daya manusia agar harapan untuk menghasilkan generasi yang unggul dalam ilmu pengetahuan dan teknologi (IPTEK) serta iman dan taqwa (imtaq) dapat tercapai.

Mengacu pada UU RI No.20 Tahun 2003 tentang Sistem Pendidikan Nasional Pasal 1, diperlukan perbaikan atas fenomena pendidikan di Indonesia, antara lain dengan menanamkan nilai-nilai Islam di dalam setiap jenjang pendidikan yang akan membentuk karakter kehidupan sehari-hari. Maka penyediaan sekolah-sekolah yang memberi nilai plus kurikulum Islam, yaitu sekolahsekolah yang selain melakukan penambahan materi pelajaran Islam dan jam belajarnya, tetapi juga sekaligus melakukan penerapan nilai-nilai Islam dalam setiap mata pelajaran adalah sebuah solusi.

Seiring berjalannya waktu, semakin banyak sekolah-sekolah Islam muncul dalam pendidikan Islam di Asia Tenggara khususnya di Indonesia yang semakin populer, antara lain yaitu sekolah Islam terpadu (Kadir, 2009, p.2). Sekolah Islam terpadu (SIT) mulai berdiri sejak tahun 1993, dan berkembang pesat setelah reformasi. Sampai saat ini diperkirakan terdapat 1000 sekolah Islam terpadu di seluruh Indonesia. Untuk menjaga mutu dan kualitas sekolah Islam terpadu, sejumlah praktisi dan pemerhati pendidikan Islam membentuk sebuah wadah Jaringan Sekolah Islam Terpadu (JSIT). Menurut Syarifudin (2009, p.1), JSIT adalah sebuah lembaga yang berupaya untuk memberdayakan sekolah-sekolah Islam.
Sebenarnya dalam kegiatan pembelajarannya, menurut Muhab (2010, p.iii), Sekolah Islam Terpadu (SIT) telah mempunyai standar mutu SIT, yaitu: standar konsep SIT, standar isi atau kurikulum, standar pendidikan agama Islam, standar tenaga pendidik dan kependidikan, standar kompetensi lulusan, standar proses, standar pengelolaan, standar pembiayaan, standar kerja sama, standar pembinaan peserta didik, standar prasarana dan sarana, dan standar penilaian. Kedua belas standar tersebut pada dasarnya merupakan pedoman untuk mengevaluasi sekolah Islam terpadu, namun masih perlu disusun secara teknis operasional menjadi sebuah instrumen agar dapat diimplementasikan untuk keperluan evaluasi sekolah Islam terpadu agar diketahui apakah standar yang telah ditetapkan itu memenuhi tuntutan kualitas sekolah Islam terpadu.

Berdasarkan informasi yang diperoleh dari riset awal, dapat disimpulkan sementara bahwa: 1) SIT telah melaksanakan evaluasi di masing-masing sekolah secara rutin disesuaikan dengan kondisi internal masingmasing sekolah; 2) Evaluasi Diri Sekolah (EDS) belum mampu mengukur dua belas standar yang ada di sekolah Islam terpadu; 3) perlu disusun suatu instrumen yang baku dengan mengacu pada standar nasional pendidikan maupun standar mutu JSIT dalam bentuk sebuah model evaluasi penyelenggaraan sekolah Islam terpadu.

Tujuan penelitian ini adalah: 1) mengembangkan model evaluasi yang tepat sehingga dapat digunakan untuk mengevaluasi penyelenggaraan Sekolah Dasar Islam Terpadu (SDIT); 2) mendeskripsikan karakteristik instrumen dalam model evaluasi SIT yang dikembangkan; 3) mendeskripsikan efektivitas model evaluasi SIT yang dikembangkan; 4) mengetahui gambaran dan kriteria hasil evaluasi yang dilaksanakan di SDIT.

\section{Metode Penelitian}

Penelitian ini dikategorikan sebagai penelitian pengembangan dengan mengkombinasikan model evaluasi CIPP dan model Formatif-Sumatif, yang menggunakan langkah-langkah penelitian pengem-

Pengembangan Evaluasi Penyelenggaraan Sekolah - 247 Retno Wahyuningsih, Budiyono 
bangan (Research and Development) dalam rangka mengembangkan instrumen untuk mengetahui penyelenggaraan pendidikan terpadu di Sekolah Dasar Islam Terpadu (SDIT). Borg \& Gall (1989, p.781) menyatakan research and development terdiri dari suatu siklus untuk mengembangkan suatu produk, diuji lapangan, dan direvisi berdasarkan data uji lapangan. Produk pendidikan yang ingin dihasilkan dalam penelitian ini adalah suatu model evaluasi yang tepat untuk mengevaluasi penyelenggaraan di SDIT. Siklus ini terdiri dari langkah-langkah sebagai berikut: 1) information collecting (pengumpulan informasi); 2) planning (perencanaan); 3) develop preliminary form of product (mengembangkan produk awal); 4) preliminary field testing (pengujian lapangan awal); 5) main product revision (revisi pada produk utama); 6) main field testing (pengujian lapangan utama); 7) operational product revision (revisi produk operasional); 8) operational field testing (pengujian lapangan operasional); 9) final product revision (revisi produk akhir); 10) dissemination and distribution (diseminasi dan distribusi).

Pada penelitian ini terdapat tiga dimensi yang akan dievaluasi, yakni dimensi input SDIT, kualitas proses, dan output lulusan. Dimensi Input terkait dengan evaluasi konsep Sekolah Islam Terpadu, evaluasi kompetensi pendidik dan tenaga kependidikan (dalam bypothetic construct disingkat kompetensi pendidik), evaluasi sarana prasarana dan pengelolaan pusat sumber belajar (dalam bypothetic construct disingkat sarana), dan evaluasi kurikulum. Dimensi kualitas proses meliputi evaluasi pengelolaan, evaluasi kerjasama, evaluasi proses, evaluasi penilaian, evaluasi Pendidikan Agama Islam (PAI), dan evaluasi pembinaan siswa. Dimensi sumatif mengevaluasi output lulusan.

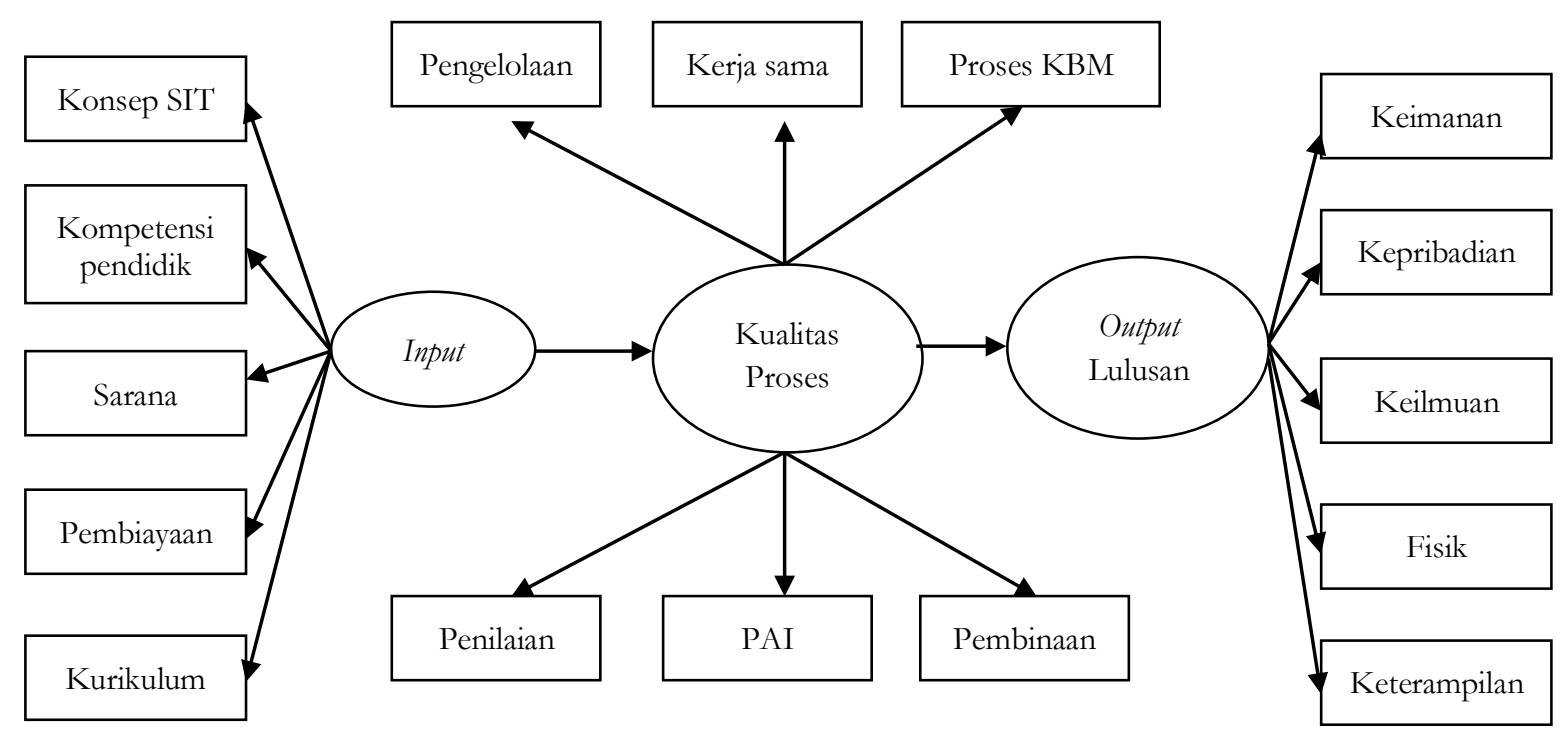

Gambar 1. Hypothetic Construct Model EPSIT

Penelitian ini dilakukan di wilayah eks Karesidenan Surakarta dengan unit analisis pengembangan model evaluasi adalah Sekolah Islam Terpadu yang terdapat di wilayah tersebut. Mengingat keterbatasan peneliti, maka tidak seluruh Sekolah Islam Terpadu diteliti. Sekolah Islam Terpadu yang diteliti adalah perwakilan dari Sekolah Dasar Islam Terpadu (SDIT). Penelitian ini menggunakan teknik sampling acak, yaitu acak pertama dilakukan untuk menentukan sampel wila- yah kabupaten/kota, acak kedua untuk menentukan perwakilan Sekolah Dasar Islam Terpadu di wilayah tersebut. Unit analisis dalam penelitian ini adalah penyelenggara sekolah dasar Islam terpadu dengan subjek penelitian yang disajikan pada Tabel 1 .

Secara keseluruhan penelitian pengembangan ini melibatkan 814 responden yang merupakan bagian dari unit analisis SIT, yang diperinci dalam Tabel 2. 
Tabel 1. Subjek Penelitian

\begin{tabular}{ll}
\hline \multicolumn{1}{c}{ Subjek } & \multicolumn{1}{c}{ Peran } \\
\hline Siswa Sekolah Dasar Islam Terpadu & - Partisipan dalam kegiatan pembelajaran integratif. \\
& - Tolok ukur keberhasilan model \\
& - Narasumber dalam pengembangan model EPSIT \\
\hline $\begin{array}{l}\text { Kepala sekolah, wakil kepala sekolah, guru, } \\
\text { tenaga administrasi, pustakawan, laboran, dan }\end{array}$ & - Penyelenggara sekolah yang mengimplementasikan \\
wali kelas Sekolah Dasar Islam Terpadu & model pendidikan terpadu. \\
\hline $\begin{array}{l}\text { Pengelola SIT (Ketua Yayasan, Pengurus, } \\
\text { staf, anggota) }\end{array}$ & - Penangumber dalam evaluasi model EPSIT \\
\hline $\begin{array}{l}\text { Pakar dan Praktisi evaluasi, pendidkan, dan } \\
\text { sekolah Islam Terpadu }\end{array}$ & $\begin{array}{l}\text { - Penilai instrumen model EPSIT yang } \\
\text { dikembangkan }\end{array}$ \\
\hline
\end{tabular}

Tabel 2. Subjek Uji Coba Pengembangan

\begin{tabular}{lccccc}
\hline \multirow{2}{*}{ Komponen Subjek } & Penelitian & Penilaian & \multicolumn{2}{c}{ Uji Coba } & Jumlah \\
\cline { 1 - 4 } \cline { 4 - 5 } & pendahuluan & Pakar & Utama & Operasional nn & \\
\hline Kepala Sekolah & 6 & 0 & 3 & 5 & 14 \\
Wakil Kep. Sekolah & 6 & 0 & 2 & 10 & 18 \\
Guru & 6 & 0 & 52 & 78 & 136 \\
Siswa & 0 & 0 & 212 & 374 & 586 \\
Tenaga Administrasi & 0 & 0 & 9 & 9 & 18 \\
Pustakawan & 0 & 0 & 2 & 4 & 6 \\
Laboran & 0 & 0 & 1 & 2 & 3 \\
Wali Kelas & 0 & 0 & 3 & 13 & 16 \\
Pengurus yayasan & 2 & 0 & 1 & 4 & 7 \\
Pakar dan Praktisi & 1 & 9 & 0 & 0 & 10 \\
\hline Jumlah & 21 & 9 & 285 & 499 & 814 \\
\hline
\end{tabular}

Instrumen yang dikembangkan dalam model EPSIT yaitu: 1) Instrumen input penyelenggaraan SIT; 2) Instrumen kualitas proses penyelenggaraan SIT; 3) Instrumen output lulusan SIT. Adapun perangkat yang menyertai model EPSIT adalah: 1) Panduan evaluasi penyelenggaraan SIT; 2) Format laporan hasil evaluasi penyelenggaraan SIT. Sedangkan instrumen lembar penilaian untuk model EPSIT adalah: 1) Lembar penilaian instrumen oleh penyelenggara SIT; 2) Lembar penilaian instrumen oleh siswa SIT; 3) Lembar penilaian oleh pakar.

Berdasarkan jenis instrumen yang telah dipaparkan, maka metode pengumpulan data dalam instrumen model evaluasi yang dikembangkan dalam penelitian ini antara lain angket dan dokumentasi. Pencarian data menggunakan angket dalam penelitian ini dilaksanakan untuk menggali pandangan, persepsi, maupun sikap responden menge- nai indikator yang ada dalam model evaluasi penyelenggaraan sekolah Islam terpadu. Metode ini dipilih karena unit analisisnya adalah sekolah dengan jumlah subjek yang cukup banyak sehingga diambil sampel yang dapat mewakili unit analisis tersebut. Angket digunakan untuk mengungkap data yang berhubungan dengan data input, kualitas proses, dan output lulusan. Dalam penelitian ini digunakan beberapa jenis angket yaitu untuk kepala sekolah, guru, tenaga administrasi, pustakawan, laboran, wali kelas, siswa, praktisi SIT, dan pengurus yayasan.

Dokumentasi digunakan untuk memperoleh informasi yang lebih akurat, misalnya untuk data input berkenaan dengan struktur kurikulum pembelajaran terpadu, untuk data formatif misalnya rencana pembelajaran, sarana dan prasarana belajar, data sumatif berupa nilai kognitif pelajaran umum dan PAI serta nilai psikomotorik be- 
rupa praktek PAI yang merupakan kompetensi siswa.

Penelitian ini dilakukan dalam dua tahapan. Tahap pertama yaitu tahap penelitian yang merupakan langkah pengumpulan informasi dalam teori $\mathrm{R} \& \mathrm{D}$ dari Borg and Gall. Pada tahap ini dilakukan penelitian pendahuluan untuk mengetahui kebutuhan mengenai model evaluasi penyelenggaraan sekolah Islam terpadu. Tahap kedua adalah tahap pengembangan yang terdiri dari langkah kedua sampai kesembilan R\&D Borg and Gall. Apabila diringkas, maka langkah penelitian ini terdiri dari tahap-tahap berikut.

Pertama, Penelitian Pendahuluan, yaitu merupakan bagian yang penting bagi seseorang yang akan menerapkan penelitian dengan metode R\&D. Diawali dengan riset atau penelitian, kemudian dilanjutkan dengan development atau pengembangan.

Kedua, Konstruk Teoritik, yaitu dimulai dari telaah konsep, teori dan hasil penelitian terdahulu. Hasil konstruk teori berupa instrumen yang merupakan penjabaran dari dua belas standar mutu JSIT yang dirangkum dalam sebuah model evaluasi untuk mengevaluasi penyelenggaraan Sekolah Islam Terpadu.

Ketiga, Teknik Delphi, adalah suatu teknik peramalan interaktif dan sistematis berdasar pada masukan-masukan secara individual dari ahli terpilih dalam dua atau lebih putaran. Dalam penelitian ini, teknik Delphi digunakan pada tahap pengembangan produk awal (Develop preliminary of product). Adapun pihak yang terlibat adalah para praktisi evaluasi, praktisi pendidikan, dan praktisi sekolah Islam terpadu.

Keempat, Uji Coba Instrumen, dilakukan untuk membuktikan validitas, mengestimasi reliabilitas, serta penilaian responden (reviewer) mengenai model EPSIT. Uji coba dilakukan dalam dua tahap, yaitu uji coba pada utama dan uji coba dalam skala luas atau uji coba operasional.

Dengan demikian model EPSIT dinilai dari dua cara, yang pertama yaitu secara objektif berdasarkan hasil evaluasi SDIT yang dapat ditentukan validitas dan reliabilitasnya, sedangkan yang kedua adalah secara subjektif berdasarkan penilaian dari para pengguna (reviewer) model EPSIT, berupa gambaran deskriptif model yang meliputi penilaian mengenai format, substansi, dan prosedur evaluasi.

Validitas bermakna sejauh mana ketepatan dan kecermatan suatu alat ukur dalam melakukan fungsi ukurnya (Azwar, 2011, p.5). Validitas dalam penelitian ini dibuktikan dengan dua cara, yaitu membuktikan validitas isi oleh pakar dan validitas empirik. Validitas isi yaitu sebuah upaya yang dilakukan untuk membuktikan validitas instrumen oleh para pakar. Validasi pakar sebagai salah satu membuktikan validitas isi adalah langkah penting dalam suatu penelitian.

Validitas empirik dibuktikan dengan construct validity yaitu untuk mengetahui sejauh mana instrumen tersebut mengukur sifat bangunan pengertian atau konstruk tertentu. Validitas ini dibuktikan dengan analisis faktor merupakan salah satu teknik statistik multivariat. Tujuannya adalah untuk mengelompokkan data menjadi beberapa kelompok sesuai dengan saling korelasi antarvariabel.

Reliabilitas merupakan terjemahan dari kata reliability yang berasal dari kata rely dan ability (Azwar, 2011, p.4). Reliabilitas dapat juga diartikan sebagai keterpercayaan, keterandalan, keajegan, kestabilan, dan konsistensi, namun ide pokok yang terkandung dalam konsep reliabilitas adalah sejauh mana hasil suatu pengukuran dapat dipercaya.

Mengacu pada metode One Shot, maka reliabilitas instrumen dalam penelitian ini diukur menggunakan Cronbach Alpha dengan bantuan program SPSS 17. Instrumen dikatakan reliabel jika memiliki koefisien reliabilitas sekurang-kurangnya 0,60.

Teknik analisis data yang digunakan dalam penelitian ini adalah deskriptif kuantitatif yang secara spesifik dikaitkan dengan tahap pengembangan serta didasarkan pada jenis data dan teknik pengumpulan data yang dilakukan.

Analisis data hasil uji coba utama dan uji coba operasional digunakan untuk membuktikan validitas konstruk dan mengestimasi reliabilitas instrumen dalam model 
EPSIT. Membuktikan validitas dilakukan menggunakan EFA dengan bantuan program SPSS 17 dan Lisrel, sedangkan mengestimasi reliabilitas diketahui melalui para- meter Cronbach Alpha dengan bantuan program SPSS 17. Rangkuman teknik analisis data dalam penelitian ini disajikan pada Tabel 3.

Tabel 3. Rangkuman Analisis Data

\begin{tabular}{ll}
\hline \multicolumn{1}{c}{ Teknik Analisis Data } & \multicolumn{1}{c}{ Penggunaan } \\
$\begin{array}{l}\text { Statistik deskriptif dengan program } \\
\text { excel }\end{array}$ & $\begin{array}{l}\text { Menghitung mean, persentase dan penetapan kriteria yang } \\
\text { diperoleh dari penelitian pendahuluan, teknik Delphi, validasi } \\
\text { pakar, maupun lembar penilaian instrumen oleh reviewer }\end{array}$ \\
\hline $\begin{array}{l}\text { Exploratory Factor Analysis (EFA) } \\
\text { dengan program SPSS 17 }\end{array}$ & $\begin{array}{l}\text { Uji validitas konstruk instrumen model EPSIT yang diperoleh } \\
\text { dari uji coba utama, dan uji coba operasional }\end{array}$ \\
\hline $\begin{array}{l}\text { Confirmatory Factor Analysis (CFA) } \\
\text { dengan program Lisrel }\end{array}$ & $\begin{array}{l}\text { Uji validitas konstruk instrumen kompetensi siswa yang } \\
\text { diperoleh dari uji coba utama, dan uji coba operasional }\end{array}$ \\
\hline $\begin{array}{l}\text { Cronbach Alpha dengan program } \\
\text { SPSS 17 }\end{array}$ & $\begin{array}{l}\text { Uji reliabilitas instrumen yang diperoleh dari uji coba utama } \\
\text { dan uji coba operasional }\end{array}$ \\
\hline
\end{tabular}

Penyelenggaraan sekolah Islam terpadu dikatakan baik, apabila memenuhi 12 standar evaluasi EPSIT. Lebih jelasnya, sekolah dikatakan mampu menyelenggarakan pendidikannya secara baik bila komponen, dimensi, maupun indikator EPSIT telah sesuai dengan standar mutu yang ditetapkan JSIT.

Tabel 4. Kriteria Penyelenggaraan SIT

\begin{tabular}{ccc}
\hline No & Skor & Kategori \\
\hline 1 & $1-1,599$ & Sangat Buruk \\
2 & $1,6-2,199$ & Buruk \\
3 & $2,2-2,799$ & Cukup \\
4 & $2,8-3,399$ & Baik \\
5 & $3,4-4,0$ & Sangat Baik \\
\hline
\end{tabular}

\section{Hasil Penelitian dan Pembahasan}

Pada tahap Develop preliminary form of product (Mengembangkan produk awal), dilakukan dengan teknik Delphi. Instrumen yang kembali kepada peneliti selanjutnya dianalisis secara kuantitatif dan disajikan dalam tabel distribusi frekuensi untuk dihitung reratanya dan dikategorisasi apakah indikator model evaluasi yang dinilai berkategori sangat penting, penting, kurang penting, atau tidak penting untuk dimunculkan dalam model evaluasi penyelenggaraan sekolah Islam terpadu. Secara kuantitatif semua komponen dan dimensi penyelenggaraan SIT pada Delphi putaran 1 memenuhi kriteria "sangat penting" untuk dimunculkan dalam model evaluasi SIT. Kegiatan Delphi putaran kedua dilaksanakan mulai 20 Mei30 Mei 2013, dilakukan dengan cara mendatangi responden ke tempat masing-masing, memberikan instrumen untuk dikerjakan, dan diambil kembali seminggu kemudian. Secara kuantitatif dalam Delphi putaran kedua menunjukkan bahwa tiga komponen dan dimensi penyelenggaraan SIT memenuhi kriteria "penting", dan sisanya memenuhi kriteria "sangat penting", sehingga layak untuk dimunculkan dalam model EPSIT.

Tahap Preliminary Field Testing, yaitu meminta penilaian instrumen oleh pakar dimaksudkan untuk memperoleh informasi awal tentang kejelasan instrumen dalam model evaluasi yang dikembangkan. Pada tahap ini dilakukan validasi ahli mengenai model evaluasi yang telah melalui penilaian sebelumnya oleh reviewer, yaitu para pakar maupun praktisi pendidikan dalam teknik Delphi. Responden dalam pengujian ini adalah para pakar dan praktisi pendidikan, evaluasi, SIT, dan agama Islam sebanyak 7 orang. Secara kuantitatif semua komponen dan dimensi penyelenggaraan SIT berdasarkan penilaian para pakar memenuhi kriteria 
"sangat baik" dan hanya satu yang berkriteria "baik" untuk digunakan dalam mengevaluasi penyelenggaraan SIT.

Tahap Main field testing (Pengujian lapangan utama) dilakukan di tiga sekolah, yaitu SDIT Nur Hidayah Surakarta, SDIT Mutiara Insan Sukoharjo, dan SDIT Al Huda Wonogiri. Pelaksanaan dilakukan bulan September-Oktober 2013. Responden meliputi penyelenggara sekolah dan siswa di sekolah tersebut. Berdasarkan rata-rata hasil uji coba di tiga SDIT, dari 24 aspek penilaian terhadap model evaluasi, delapan belas diantaranya mencapai persentase di atas $76 \%$ (sangat baik), sedangkan tujuh aspek, yaitu ketebalan halaman, pedoman evaluasi, waktu untuk mengerjakan, pelaksanaan evaluasi, analisis data, penetapan kriteria, dan penyusunan laporan evaluasi mencapai persentase di atas 51\% (baik). Apabila hasil evaluasi yang dilakukan di ketiga sekolah tersebut dibandingkan, maka secara umum SDIT Al Huda adalah yang paling baik penyelenggaraannya dengan skor 3,73 (sangat baik), dilanjutkan oleh SDIT Nur Hidayah dengan skor 3,62 (sangat baik), dan berikutnya SDIT Mutiara Insan Sukoharjo dengan skor 3,22 (baik).

Berdasarkan hasil uji coba lapangan utama, tahap selanjutnya adalah revisi produk untuk persiapan uji coba operasional. Pada tahap ini draf model yang berupa in- strumen beserta indikator-indikatornya, yang telah diuji coba pada tahap utama diperbaiki berdasarkan masukan dari responden uji coba utama. Bersamaan dengan perbaikan lebih lanjut pada masing-masing instrumen, maka dilakukan analisis data berdasarkan angket evaluasi yang telah diisi oleh responden untuk tiap-tiap instrumen dengan tujuan untuk mengetahui reliabilitas dan validitasnya. Untuk menguji validitas dan reliabilitas instrumen digunakan EFA dengan program SPSS 17, sedangkan untuk instrumen kompetensi lulusan diperkuat dengan program Lisrel.

Output Lisrel berupa measurement equation menghasilkan estimasi mengenai hubungan antara indikator dengan variabel laten sekaligus menguji validitas indikator dalam merefleksikan variabel laten (unobserved). Dari output Lisrel diketahui bahwa kesebelas indikator dalam instrument kompetensi lulusan memiliki nilai $\mathrm{R}^{2}$ di atas 0,10 , sehingga disimpulkan bahwa sebelas indikator tersebut cukup baik dalam merepresentasikan variabel laten dan valid. Hasil goodness of fit output Lisrel diperoleh fakta bahwa instrumen kompetensi lulusan memiliki fit yang cukup baik. Model pengukuran menghasilkan nilai estimasi yang menggambarkan faktor loading masing-masing indikator.

Tabel 5. Goodness of Fit Instrumen Kompetensi Lulusan

\begin{tabular}{cccc}
\hline No & Kriteria & $\begin{array}{c}\text { Goodness of fit } \\
\text { (Byrne:1998) }\end{array}$ & Hasil analisis \\
\hline 1 & Derajat bebas (db) & $<2 \mathrm{db}$ & 33 \\
2 & Chi square & $\geq 0,05$ & 44,17 \\
3 & Signifikansi (p) & $<0,08$ & 0,093 \\
4 & RMSEA & $\geq 0,90$ & 0,040 \\
5 & Goodnees of Fit Index (GFI) & $\geq 0,90$ & 0,96 \\
6 & Adjusted Goodnees of Fit Index (AGFI) & $\geq 0,90$ & 0,93 \\
7 & Normed Fit Index (NFI) & $\geq 0,95$ & 0,98 \\
8 & Comparatif Fit Index (CFI) & $\geq 0,95$ & 1,00 \\
9 & Incremental Fit Index (IFI) & & 1,00 \\
\hline
\end{tabular}

Uji EFA dengan program SPSS 17 bertujuan untuk menguji apakah suatu konstruk mempunyai unidimensionalitas atau apakah indikator-indikator yang digunakan dapat mengkonfirmasikan sebuah konstruk atau variabel. Alat uji dalam EFA yang digunakan untuk mengukur tingkat interkorelasi antarvariabel adalah Kaiser-meyes-Olkin 
Measure of sampling Adequacy (KMO MSA). Nilai KMO bervariasi yang dikehen-daki harus $\geq 0,50$ untuk dapat dilakukan analisis faktor. Berdasarkan Tabel 6 menunjukkan bahwa seluruh nilai $\mathrm{KMO} \geq 0,50$. Mengacu pada nilai yang diperoleh dan dibandingkan dengan parameter validitas empirik, disimpulkan bahwa dua puluh instrumen dalam model EPSIT valid.

Melengkapi uji validitas instrumen dalam model EPSIT dilakukan pula uji reliabilitas dengan bantuan program SPSS 17. Parameter untuk menentukan reliabilitas instrumen dalam SPSS 17 yaitu Alpha Cronbach. Instrumen dikatakan reliabel jika nilai
Alpha Cronbach >0,60. Menurut Hair, et.all (1998) dalam Ghozali (2009, p.48), apabila nilai Alpha $<0,60$ hal ini mengindikasikan ada beberapa responden yang menjawab tidak konsisten dan harus dilihat satu per satu. Jawaban responden yang tidak konsisten harus dibuang dari analisis dan alpha akan meningkat. Hasil uji reliabilitas pada uji coba utama menunjukkan bahwa semua instrumen dalam model EPSIT memiliki nilai Alpha Cronbach $>0,60$, bahkan rata-rata diatas 0,90 . Hanya empat instrumen yang memiliki nilai alpha cronbach di atas 0,80 . Sehingga disimpulkan bahwa seluruh instrumen EPSIT reliabel.

Tabel 6. Hasil Analisis Faktor Konfirmatory pada Uji Coba Utama

\begin{tabular}{|c|c|c|c|c|c|c|c|c|}
\hline \multirow{3}{*}{ No } & \multirow{3}{*}{ Instrumen Evaluasi } & \multirow{3}{*}{$\mathrm{n}$} & \multirow{3}{*}{$\begin{array}{l}\text { Jumlah } \\
\text { indikator }\end{array}$} & \multicolumn{4}{|c|}{ Validitas } & \multirow{3}{*}{$\begin{array}{c}\text { Reliabilitas } \\
\alpha .\end{array}$} \\
\hline & & & & \multirow[t]{2}{*}{$\mathrm{KMO}$} & \multirow{2}{*}{$\begin{array}{l}\text { Total \% } \\
\text { Variance }\end{array}$} & \multicolumn{2}{|c|}{$\begin{array}{c}\text { Loading Factor } \\
\text { (principal component 1) }\end{array}$} & \\
\hline & & & & & & Terendah & Tertinggi & \\
\hline 1 & Konsep SDIT & 6 & 3 & 0,609 & 99,29 & 0,994 & 0,999 & 0,996 \\
\hline 2 & Sarana Prasarana & 6 & 4 & 0,500 & 91,41 & 0,919 & 0,988 & 0,968 \\
\hline 3 & Pengelolaan pusat belajar & 6 & 3 & 0,583 & 80,63 & 0,766 & 0,968 & 0,875 \\
\hline 4 & Pembiayaan & 6 & 5 & 0,773 & 98,45 & 0,974 & 0,999 & 0,996 \\
\hline 5 & Pengelolaan & 6 & 3 & 0,727 & 89,64 & 0,915 & 0,969 & 0,942 \\
\hline 6 & Tenaga Pendidik & 6 & 4 & 0,709 & 97,91 & 0,983 & 0,997 & 0,993 \\
\hline 7 & Kompetensi kepala sekolah & 6 & 3 & 0,520 & 99,03 & 0,992 & 1,000 & 0,995 \\
\hline 8 & Kompetensi guru & 53 & 5 & 0,773 & 62,25 & 0,533 & 0,926 & 0,838 \\
\hline 9 & Kompetensi TU & 20 & 4 & 0,593 & 64,46 & 0,605 & 0,945 & 0,806 \\
\hline 10 & Kompetensi Laboran & 4 & 2 & 0,500 & 99,58 & 0,997 & 0,998 & 0,995 \\
\hline 11 & Kompetensi pustakawan & 6 & 3 & 0,785 & 99,49 & 0,997 & 0,998 & 0,997 \\
\hline 12 & Kerja sama & 6 & 4 & 0,548 & 92,02 & 0,923 & 0,992 & 0,971 \\
\hline 13 & Kurikulum & 6 & 3 & 0,589 & 95,25 & 0,960 & 0,995 & 0,975 \\
\hline 14 & Pendidikn Agama Islam & 6 & 3 & 0,629 & 94,29 & 0,952 & 0,992 & 0,970 \\
\hline 15 & Pembinaan siswa & 6 & 3 & 0,589 & 75,29 & 0,682 & 0,954 & 0,826 \\
\hline 16 & Dokumen Pembelajaran & 6 & 4 & 0,555 & 97,51 & 0,980 & 0,995 & 0,991 \\
\hline 17 & Penilaian & 6 & 3 & 0,603 & 90,60 & 0,932 & 0,987 & 0,948 \\
\hline 18 & Keg. Belajar Mengajar & 6 & 2 & 0,500 & 99,93 & 0,500 & 0,500 & 0,999 \\
\hline 19 & Dok. Kompetensi Lulusan & 6 & 4 & 0,604 & 98,57 & 0,992 & 0,997 & 0,967 \\
\hline 20 & Kompetensi Lulusan & 212 & 11 & 0,916 & 53,79 & 0,517 & 0,839 & 0,912 \\
\hline
\end{tabular}

Melengkapi bukti validitas dan estimasi reliabilitas, dilakukan pula analisis deskriptif terhadap penilaian reviewer SDIT mengenai model EPSIT. Masing-masing instrumen dinilai oleh responden yang mengerjakannya. Angket evaluasi guru dinilai oleh guru, angket evaluasi kepala sekolah dinilai oleh kepala sekolah.
Analisis dilakukan dengan menjumlahkan seluruh skor yang diperoleh dan membaginya dengan jumlah skor maksimum kemudian mengalikannya dengan 100 , sehingga didapatkan persentase yang menunjukkan seberapa baik instrumen tersebut menurut mereka. Jika persentase $>76 \%$ maka instrumen tersebut memiliki kriteria 
sangat baik. Hasil analisis deskriptif menunjukkan bahwa seluruh instrumen mencapai persentase $>76 \%$ sehingga disimpul- kan bahwa instrumen EPSIT memiliki kriteria "sangat baik.

Tabel 7. Hasil Analisis Deskriptif pada Uji Coba Utama

\begin{tabular}{clccl}
\hline No & Instrumen Evaluasi & Mean & $\%$ & Kriteria \\
\hline 1 & Konsep SDIT & 3,826 & 95,65 & Sangat baik \\
2 & Sarana Prasarana & 3,826 & 95,65 & Sangat baik \\
3 & Pengelolaan pusat sumber belajar & 3,826 & 95,65 & Sangat baik \\
4 & Pembiayaan & 3,826 & 95,65 & Sangat baik \\
5 & Pengelolaan & 3,826 & 95,65 & Sangat baik \\
6 & Tenaga Pendidik & 3,826 & 95,65 & Sangat baik \\
7 & Kompetensi kepala sekolah & 3,674 & 91,84 & Sangat baik \\
8 & Kompetensi guru & 3,315 & 82,88 & Sangat baik \\
9 & Kompetensi TU & 3,681 & 92,03 & Sangat baik \\
10 & Kompetensi Laboran & 3,586 & 89,67 & Sangat baik \\
11 & Kompetensi pustakawan & 3,420 & 81,52 & Sangat baik \\
12 & Kerjasama & 3,826 & 95,65 & Sangat baik \\
13 & Kurikulum & 3,826 & 95,65 & Sangat baik \\
14 & Pendidikan Agama Islam & 3,826 & 95,65 & Sangat baik \\
15 & Pembinaan siswa & 3,826 & 95,65 & Sangat baik \\
16 & Dokumen Proses Pembelajaran & 3,826 & 95,65 & Sangat baik \\
17 & Penilaian & 3,826 & 95,65 & Sangat baik \\
18 & Proses Pembelajaran & 3,536 & 88,40 & Sangat baik \\
19 & Dokumen Kompetensi Lulusan & 3,826 & 95,65 & Sangat baik \\
20 & Kompetensi Lulusan & 3,674 & 85,50 & Sangat baik \\
\hline
\end{tabular}

Berdasarkan hasil analisis data sebelumnya, ditambah saran masukan responden pada kolom angket evaluasi dan pendalaman melalui wawancara, maka tahap selanjutnya dilakukan perbaikan pada model EPSIT. Perbaikan yang dilakukan pada tahap ini adalah jika semula angket yang dalam pengerjaannya, responden memberikan tanggapannya dengan cara menuliskan skor 1,2, 3, 4 pada lembar tanggapan yang sudah disediakan berdasarkan petunjuk (rubrik) pada angket, maka untuk lebih memudahkan responden dalam memberikan tanggapan, dibuatkan opsi jawaban a, b, c, dan d, sehingga responden tinggal memberi tanda silang pada huruf yang sesuai dengan kondisinya. Di samping itu responden tetap diminta memberikan penjelasan dan perbaikan yang dilakukan untuk memenuhi data faktual evaluasi.

Perbaikan lainnya dilakukan pada angket kompetensi lulusan dan angket identitas konsep sekolah. Berdasarkan masukan dari beberapa wali kelas VI di SDIT Nur Hidayah Surakarta dan SDIT Mutiara Insan Sukoharjo, bahwa siswa merasa kesulitan untuk menuliskan skor 1-4 dalam rangka menggambarkan kondisinya masing-masing, sehingga perlu dibuat pilihan jawaban yang jelas, agar siswa dengan mudah menggambarkan kondisi dirinya. Untuk itu angket evaluasi kompetensi lulusan dibuat dengan menambahkan opsi pilihan tanggapan yang dapat dengan mudah dipilih oleh siswa. Untuk melengkapi penilaian model EPSIT, peneliti membuat instrumen penilaian untuk angket evaluasi kompetensi lulusan yang dikerjakan oleh siswa. Berjumlah 15 butir, instrumen ini disusun dengan bahasa yang mudah dipahami oleh siswa yang berumur lebih kurang 12 tahun.

Tahap selanjutnya adalah Operational Field Testing (Pengujian Lapangan Operasional) diterapkan pada responden dalam 
lingkup yang lebih luas yaitu penyelenggara dan siswa Sekolah Islam Terpadu (SIT) di lima SDIT di eks Karesidenan Surakarta, yaitu SDIT As Salamah Baturetno Wonogiri, SDIT Insan Kamil Karanganyar, SDIT Az Zahra Sragen, SDIT Arofah Boyolali dan SDIT Hidayah Klaten. Pada tahap ini produk yang dihasilkan berupa instrumen evaluasi Sekolah Islam Terpadu yang diharapkan dapat memperoleh informasi yang praktis dan efisien tentang pelaksanaan pendidikan Sekolah Islam Terpadu.
Sebagaimana pada uji coba utama, maka pada uji coba operasional seluruh instrumen diuji validitasnya dengan EFA program SPSS17, dan hanya instrumen kompetensi lulusan analisisnya dilengkapi dengan CFA program Lisrel. Hal ini disebabkan jumlah responden cukup proporsional dibandingkan jumlah indikator. Jumlah responden di lima sekolah adalah 374 siswa kelas VI dengan jumlah butirnya adalah 99 dengan sebelas indikator.

Tabel 8. Goodness of Fit Instrumen Kompetensi Lulusan

\begin{tabular}{cccc}
\hline No & Kriteria & $\begin{array}{c}\text { Goodness of fit } \\
\text { (Byrne, 1998) }\end{array}$ & Hasil analisis \\
\hline 1 & Derajat bebas (db) & 25 \\
2 & Chi square & $<2 \mathrm{db}$ & 32,25 \\
3 & Signifikansi (p) & $\geq 0,05$ & 0,150 \\
4 & RMSEA & $<0,08$ & 0,028 \\
5 & Goodnees of Fit Index (GFI) & $\geq 0,90$ & 0,98 \\
6 & Adjusted Goodnees of Fit Index (AGFI) & $\geq 0,90$ & 0,96 \\
7 & Normed Fit Index (NFI) & $\geq 0,90$ & 0,99 \\
8 & Comparatif Fit Index (CFI) & $\geq 0,95$ & 1,00 \\
9 & Incremental Fit Index (IFI) & $\geq 0,95$ & 1,00 \\
\hline
\end{tabular}

Hasil measurement equation program Lisrel menghasilkan estimasi mengenai hubungan antara indikator dengan variabel laten sekaligus menguji validitas indikator dalam merefleksikan variabel laten (unobserved). Dari output Lisrel, dapat diketahui bahwa kesebelas indikator memiliki nilai $\mathrm{R}^{2}$ diatas 0,10 , sehingga disimpulkan bahwa sebelas indikator tersebut cukup baik dalam merepresentasikan variabel laten (valid). Adapun hasil estimasi model pengukuran juga menunjukkan bahwa indikator kompetensi lulusan memiliki loading factor yang cukup untuk dikatakan valid, yaitu diatas 0,60 .

Sebagaimana uji coba utama, maka tahap selanjutnya dibuktikan validitas instrumen untuk seluruh instrumen dalam model EPSIT menggunakan EFA dengan program SPSS 17 sebagaimana telah dilakukan pada instrumen kompetensi lulusan. Adapun untuk melengkapi bukti validitas instrumen dalam model EPSIT dilakukan pula estimasi reliabilitas dengan bantuan program SPSS 17. Hasil pembuktian validitas seluruh instrumen evaluasi dalam model EPSIT pada uji coba operasional, menunjukkan bahwa semua indikator mengelompok pada 1 faktor. Hal ini mengindikasikan bahwa semua indikator mengarah pada satu instrumen. Uji Bartlett of Sphericity merupakan uji untuk menentukan ada tidaknya korelasi antar indikator. Semakin kecil nilai Bartlett test, $(<0,05)$ menunjukkan semakin kuat korelasi antarindikator. Tabel 9 menunjukkan bahwa seluruh nilai Bartlett test $<0,05$. Alat uji lain yaitu Kaiser-meyes-Olkin Measure of sampling Adequacy (KMO MSA) menghendaki nilai harus $\geq 0,50$ untuk dapat dilakukan analisis faktor. Berdasarkan Tabel 9 menunjukkan bahwa seluruh nilai $\mathrm{KMO} \geq$ 0,50. Mengacu pada nilai yang diperoleh dan dibandingkan dengan parameter validitas, disimpulkan bahwa dua puluh instrumen dalam model EPSIT valid. 
Hasil estimasi reliabilitas pada uji coba operasional menunjukkan bahwa semua instrumen dalam model EPSIT memiliki nilai Alpha Cronbach $>0,60$, bahkan dua belas instrumen diatas 0,90 . Hanya dua instrumen yaitu angket evaluasi sarana dan kepala sekolah yang memiliki nilai Alpha 0,648 dan 0,786 . Sehingga disimpulkan bahwa seluruh instrumen EPSIT reliabel.

Tabel 9. Hasil Pembuktian Validitas dan Estimasi Reliabilitas pada Uji Coba Operasional

\begin{tabular}{|c|c|c|c|c|c|c|c|c|}
\hline \multirow{3}{*}{ No } & \multirow{3}{*}{ Instrumen Evaluasi } & \multirow{3}{*}{$\mathrm{n}$} & \multirow{3}{*}{$\begin{array}{l}\text { Jumlah } \\
\text { indikator }\end{array}$} & \multicolumn{4}{|c|}{ Validitas } & \multirow{3}{*}{$\begin{array}{c}\text { Reliabilitas } \\
\alpha .\end{array}$} \\
\hline & & & & \multirow[t]{2}{*}{$\mathrm{KMO}$} & \multirow{2}{*}{$\begin{array}{l}\text { Total \% } \\
\text { Variance }\end{array}$} & \multicolumn{2}{|c|}{$\begin{array}{c}\text { Loading Factor } \\
\text { (principal component 1) }\end{array}$} & \\
\hline & & & & & & Terendah & Tertinggi & \\
\hline 1 & Konsep SDIT & 10 & 3 & 0,625 & 78,84 & 0,763 & 0,953 & 0,861 \\
\hline 2 & Sarana Prasarana & 10 & 4 & 0,506 & 85,47 & 0,846 & 0,974 & 0,648 \\
\hline 3 & Pengelolaan pusat & 10 & 3 & 0,729 & 88,10 & 0,914 & 0,962 & 0,932 \\
\hline 4 & Pembiayaan & 10 & 5 & 0,670 & 66,35 & 0,533 & 0,981 & 0,858 \\
\hline 5 & Pengelolaan & 10 & 3 & 0,772 & 99,79 & 0,998 & 0,999 & 0,999 \\
\hline 6 & Tenaga Pendidik & 10 & 4 & 0,712 & 92,04 & 0,920 & 0,993 & 0,971 \\
\hline 7 & Kompetensi kepala sekolah & 10 & 4 & 0,798 & 81,19 & 0,842 & 0,946 & 0,786 \\
\hline 8 & Kompetensi guru & 78 & 5 & 0,797 & 62,90 & 0,671 & 0,842 & 0,851 \\
\hline 9 & Kompetensi TU & 24 & 4 & 0,845 & 98,49 & 0,984 & 0,996 & 0,911 \\
\hline 10 & Kompetensi Laboran & 4 & 3 & 0,521 & 92,94 & 0,924 & 0,984 & 0,962 \\
\hline 11 & Kompetensi pustakawan & 16 & 4 & 0,787 & 76,73 & 0,803 & 0,931 & 0,898 \\
\hline 12 & Kerjasama & 10 & 4 & 0,788 & 96,45 & 0,968 & 0,993 & 0,971 \\
\hline 13 & Kurikulum & 10 & 3 & 0,727 & 99,91 & 0,999 & 1,000 & 1,000 \\
\hline 14 & Pendidikn Agama Islam & 10 & 3 & 0,660 & 75,11 & 0,848 & 0,922 & 0,833 \\
\hline 15 & Pembinaan siswa & 10 & 3 & 0,665 & 90,16 & 0,985 & 0,997 & 0,991 \\
\hline 16 & Dokumen Pembelajaran & 10 & 4 & 0,581 & 72,29 & 0,735 & 0,917 & 0,870 \\
\hline 17 & Penilaian & 10 & 3 & 0,749 & 99,28 & 0,993 & 0,998 & 0,996 \\
\hline 18 & Keg. Belajar Mengajar & 10 & 2 & 0,500 & 98,35 & 0,992 & 0,992 & 0,983 \\
\hline 19 & Dok. Kompetensi Lulusan & 10 & 4 & 0,764 & 90,94 & 0,936 & 0,982 & 0,967 \\
\hline 20 & Kompetensi Lulusan & 374 & 11 & 0,934 & 56,63 & 0,672 & 0,837 & 0,923 \\
\hline
\end{tabular}

Analisis deskriptif menunjukkan bahwa seluruh instrumen mencapai persentase $>76 \%$ sehingga disimpulkan bahwa instrumen EPSIT memiliki kriteria sangat baik. Hasil uji analisis deskriptif instrumen model EPSIT disajikan dalam Tabel 10. Secara umum hasil uji coba operasional menunjukkan bahwa model evaluasi penyelenggaraan sekolah Islam terpadu berkategori baik sangat baik. Dari segi kepraktisan, model EPSIT dikategorikan praktis (aspek kemudahan untuk dikerjakan mencapai $92 \%$ dan aspek kemanfaatan mencapai 89,01\%). Dari segi efisiensi, model EPSIT dikategorikan efisien, karena $86,7 \%$ responden mengatakan model EPSIT lebih mudah digunakan dibandingkan dengan evaluasi diri sekolah (EDS) dan 85,5\% mengatakan model EPSIT lebih mudah digunakan dibandingkan dengan model evaluasi lain yang pernah mereka gunakan. Meskipun demikian model ini masih perlu diuji validitas dan reliabilitasnya secara empirik dalam rangka perbaikan untuk model EPSIT menjadi lebih baik.

Berdasarkan hasil analisis data sebelumnya, ditambah saran masukan responden pada kolom angket evaluasi dan pendalaman melalui wawancara, maka tahap selanjutnya dilakukan perbaikan kembali pada model EPSIT. Perbaikan yang dilakukan pada tahap ini adalah memperbaiki redaksi penulisan maupun pilihan bahasa pada per- 
nyataan dalam model evaluasi tanpa mengubah jumlah butir maupun indikator pada model evaluasi.

Perbaikan lainnya dilakukan pada angket kompetensi lulusan. Saran dan masukan responden penelitian baik pada uji coba utama maupun uji coba operasional terutama wali kelas dan siswa kelas VI, rata-rata menyebutkan bahwa jumlah butir instrumen kompetensi lulusan terlalu banyak untuk anak usia sekolah dasar. Di samping itu terdapat beberapa butir yang secara umum belum sesuai untuk diukur pada siswa tersebut, misalnya mengenai butir berusaha untuk mandiri dengan berlatih jual beli, berlatih menghasilkan uang jajan dari usaha sendiri, serta butir yang memiliki tema yang hampir sama dipilih salah satu, misalnya tentang menghindari segala bentuk perjudian. Namun berdasarkan hasil uji validitas angket evaluasi kompetensi siswa yang telah memiliki validitas konstruk yang baik, maka jumlah butir tidak berubah.

Tabel 10. Hasil analisis deskriptif pada uji coba operasional

\begin{tabular}{clccc}
\hline No & Instrumen Evaluasi & Mean & $\%$ & Kriteria \\
\hline 1 & Konsep SDIT & 3,55 & 87,98 & Sangat baik \\
2 & Sarana Prasarana & 3,63 & 87,14 & Sangat baik \\
3 & Pengelolaan pusat sumber belajar & 3,51 & 85,56 & Sangat baik \\
4 & Pembiayaan & 3,51 & 85,56 & Sangat baik \\
5 & Pengelolaan & 3,51 & 85,56 & Sangat baik \\
6 & Tenaga Pendidik & 3,51 & 85,56 & Sangat baik \\
7 & Kompetensi kepala sekolah & 3,37 & 82,61 & Sangat baik \\
8 & Kompetensi guru & 3,55 & 87,98 & Sangat baik \\
9 & Kompetensi TU & 3,37 & 84,19 & Sangat baik \\
10 & Kompetensi Laboran & 3,45 & 86,41 & Sangat baik \\
11 & Kompetensi pustakawan & 3,58 & 86,95 & Sangat baik \\
12 & Kerjasama & 3,51 & 85,56 & Sangat baik \\
13 & Kurikulum & 3,51 & 85,56 & Sangat baik \\
14 & Pendidikan Agama Islam & 3,51 & 85,56 & Sangat baik \\
15 & Pembinaan siswa & 3,51 & 85,56 & Sangat baik \\
16 & Dokumen Pembelajaran & 3,51 & 85,56 & Sangat baik \\
17 & Penilaian & 3,51 & 85,56 & Sangat baik \\
18 & Proses Belajar Mengajar & 3,55 & 87,98 & Sangat baik \\
19 & Dokumen Kompetensi Lulusan & 3,51 & 85,56 & Sangat baik \\
20 & Kompetensi Lulusan & 3,26 & 81,43 & Sangat baik \\
\hline
\end{tabular}

Produk akhir yang dihasilkan dalam penelitian ini berupa sebuah model evaluasi penyelenggaraan sekolah Islam terpadu yang dapat digunakan sebagai salah satu mekanisme kontrol sekolah, pemantauan proses penyelenggaraan sekolah, penyediaan data dasar yang harus dimiliki sekolah, serta persiapan bagi sekolah untuk menghadapi evaluasi eksternal seperti akreditasi.

Evaluasi ini menggunakan rancangan deskriptif kuantitatif yang didukung dengan data kualitatif sebagai penjelas, dengan fokus kajian gambaran kuantitatif penyelenggaraan sekolah Islam terpadu. Disain evaluasi ini diharapkan mampu melihat fakta yang terjadi pada semua komponen kegiatan penyelenggaraan sekolah Islam terpadu untuk selanjutnya akan dideskripsikan secara obyektif. EPSIT memiliki 20 jenis angket yang terdiri dari 1686 butir.

Dalam aplikasinya, dua puluh jenis angket dalam model EPSIT digunakan un- 
tuk mengukur tiga dimensi evaluasi, yaitu dimensi imput, proses, dan output. Dimensi input meliputi lima jenis angket evaluasi, yaitu konsep SIT, kompetensi pendidik, sarana, pembiayaan, dan kurikulum. Kelima jenis evaluasi ini merupakan instrumen yang memiliki validitas dan reliabilitas yang bisa diandalkan secara isi maupun empiris, oleh sebab itu dalam EPSIT dapat digunakan untuk mengevaluasi standar konsep, standar kompetensi pendidik, standar sarana, standar pembiayaan, dan standar kurikulum sebagai input dalam penyelenggaraan Sekolah Islam Terpadu.

Tabel 11. Objek evaluasi dan jumlah butir pada model EPSIT

\begin{tabular}{clc}
\hline No & \multicolumn{1}{c}{ Objek evaluasi } & Jumlah butir \\
\hline 1 & Dokumen Konsep sekolah & 12 \\
2 & Dokumen tenaga pendidik & 25 \\
3 & Kompetensi kepala sekolah & 143 \\
4 & Kompetensi guru & 144 \\
5 & Kompetensi laboran & 100 \\
6 & Kompetensi pustakawan & 115 \\
7 & Kompetensi tenaga administrasi & 113 \\
8 & Sarana prasarana & 459 \\
9 & Dokumen Pengelolaan pusat sumber belajar & 14 \\
10 & Dokumen Pembiayaan & 33 \\
11 & Dokumen Kurikulum & 23 \\
12 & Dokumen Pengelolaan & 156 \\
13 & Dokumen Kerjasama & 33 \\
14 & Dokumen KBM & 37 \\
15 & Proses KBM di kelas & 57 \\
16 & Dokumen penilaian hasil belajar & 44 \\
17 & Dokumen PAI & 23 \\
18 & Dokumen pembinaan siswa & 45 \\
19 & Dokumen kompetensi lulusan & 11 \\
20 & Kompetensi lulusan & 99 \\
\hline & & Total
\end{tabular}

Secara keseluruhan, model EPSIT telah memenuhi standar sebagai sebuah alat yang dapat digunakan untuk mengevaluasi penyelenggaraan SDIT, karena memiliki validitas dan reliabilitas yang dapat diandalkan baik validitas isi maupun validitas empiris. Disamping itu dalam uji coba yang dilakukan di delapan sekolah telah digunakan oleh penyelenggara SDIT dan dinilai "sangat baik" oleh para reviewer untuk digunakan mengevaluasi penyelenggaraan Sekolah Islam Terpadu serta mampu memberikan gambaran dan kriteria secara menyeluruh mengenai penyelenggaraan Sekolah Islam Terpadu berdasarkan dua belas standar yang terdapat di sekolah Islam terpadu.

\section{Simpulan}

Berdasarkan rumusan masalah dan pertanyaan penelitian diperoleh kesimpulan sebagai berikut.

Pertama, penelitian ini telah menghasilkan model Evaluasi Penyelenggaraan Sekolah Islam Terpadu (EPSIT). Model EPSIT dikembangkan mengacu pada teori Borg and Gall, meliputi: (a) pengumpulan informasi; (b) perencanaan; (c) pengembangan produk awal; (d) penilaian oleh pakar; (e) revisi pada produk utama; (f) pengujian lapangan utama; (g) revisi produk operasional, (h) pengujian lapangan operasional, (i) revisi produk akhir. Model EPSIT yang 
dihasilkan dikemas menjadi sepuluh (10) buku berisi 20 jenis angket evaluasi untuk mengevaluasi dua belas standar Sekolah Dasar Islam Terpadu (SDIT) yang dikelompokkan menjadi tiga dimensi input, kualitas proses, dan output, dengan rincian: (1) standar konsep SIT, kompetensi pendidik, sarana, pembiayaan, dan kurikulum dalam EPSIT dapat digunakan untuk mengevaluasi input penyelenggaraan Sekolah Islam Terpadu; (2) standar pengelolaan, kerja sama, proses kegiatan belajar mengajar, penilaian, pendidikan agama Islam, dan pembinaan siswa dalam EPSIT dapat digunakan untuk mengevaluasi kualitas proses penyelenggaraan Sekolah Islam Terpadu; (3) standar kompetensi siswa dalam EPSIT dapat digunakan untuk mengevaluasi output Sekolah Islam Terpadu.

Kedua, karakteristik instrumen dalam model EPSIT meliputi: (a) memiliki format sangat baik (rata-rata 86); (b) telah memenuhi substansi model evaluasi (rata-rata 95); (c) memiliki tingkat validitas konstruk yang dapat diandalkan, terbukti pada uji coba utama dan uji coba operasional semua indikator mengelompok pada satu faktor (unidimension); (d) memiliki tingkat reliabilitas yang tinggi, terbukti pada uji coba utama dan uji coba operasional semua instrumen memiliki nilai $\alpha$ di atas 0,61 (reliabilitas tinggi adalah $0,60-0,80)$.

Ketiga, model EPSIT memiliki tingkat efektivitas sangat baik. Hal ini terbukti $>76 \%$ pengguna di delapan SDIT dapat menggunakan dengan mudah. Dengan kata lain model tersebut telah memenuhi standar sebagai sebuah alat yang dapat digunakan untuk mengevaluasi penyelenggaraan Sekolah Dasar Islam Terpadu.

Keempat, kriteria dalam Model EPSIT dapat memberikan gambaran secara faktual dan menyeluruh mengenai penyelenggaraan Sekolah Dasar Islam Terpadu berdasarkan dua belas standar pendidikan yang terdapat di sekolah Islam terpadu, karena model EPSIT mampu: (a) menghasilkan profil sekolah yang komprehensif dengan data dan informasi up to date; (b) merencanakan dan memperbaiki sekolah se- cara berkala; (c) menjamin keterlaksanaan penyelenggaraan sekolah sesuai standar mutu JSIT; (d) memberikan informasi mengenai sekolah kepada masyarakat dan pihak yang memerlukan; (e) mempersiapkan sekolah dalam menghadapi evaluasi eksternal atau akreditasi.

Adanya keterbatasan dalam penelitian ini merupakan pijakan untuk memberikan saran penelitian sebagai berikut.

Pertama, untuk mengantisipasi adanya responden (dalam hal ini penyelenggara sekolah) yang tidak kooperatif, mengingat unit analisis model EPSIT melibatkan hampir seluruh penyelenggara sekolah serta siswa yang duduk di kelas VI, maka sebaiknya JSIT menyelenggarakan evaluasi dalam satu waktu, serta tidak meninggalkan instrumen evaluasi di sekolah untuk diambil di kemudian hari, disamping itu sebaiknya SDIT yang dievaluasi tidak memberikan kesempatan penyelenggara sekolah membawa instrumen evaluasi mengerjakan di rumah.

Kedua, waktu untuk pelaksanaan evaluasi penyelenggaraan SDIT harus benarbenar tepat dan direncanakan dengan sebaik-baiknya baik oleh JSIT sebagai evaluator maupun SDIT yang akan dievaluasi agar evaluasi penyelenggaraan SDIT dapat dilakukan secara optimal dan efisien.

Ketiga, untuk mengevaluasi standar kompetensi lulusan, perlu dipertimbangkan untuk mengukur output kompetensi lulusan dari alumni yang benar-benar telah lulus dari SDIT (tahun kelulusan dibatasi maksimal dua tahun). Tentunya hal ini dapat dilaksanakan dengan melacak posisi dan keberadaan lulusan berdasarkan data yang dimiliki oleh SDIT, namun untuk ini SDIT harus benar-benar memiliki database lulusan yang jelas dan akurat dari tahun ke tahun.

Keempat, dalam konteks pendidikan dasar, SDIT berada di bawah naungan kemendiknas, maka harus memiliki standar yang dipersyaratkan oleh kemendiknas. Disamping itu SDIT memiliki kekhasan yang tidak terakomodir dalam indikator akreditasi dan tidak masuk dalam cakupan evaluasinya padahal ini penting untuk menilai apakah SDIT telah benar-benar memiliki kekhasan 
yang seharusnya dimiliki oleh SDIT. Oleh sebab itu EPSIT sebaiknya diposisikan sebagai persiapan untuk akreditasi dan dilakukan secara berkala untuk memutaakhirkan data dan informasi dasar sekolah secara menyeluruh yang mengacu pada standar evaluasi JSIT.

\section{Daftar Pustaka}

Azwar, Saifuddin. (2011). Reliabilitas dan validitas. Yogyakarta: Pustaka Pelajar

Borg, W.R., \& Gall, M.D. (1989). Educational research: An introduction (3rd ed.). New York: Longman

Byrne, B.M. (1998). Structural equation modeling with AMOS: Basic Concepts, applications and programming. New York: Routledge Taylor and Francis Group.

Ghozali, Imam. (2009). Aplikasi analisis multivariate dengan program SPSS.
Semarang: Badan penerbit Universitas Diponegoro.

Hair, J.F., Anderson, R.E., Tatham, R.L., \& Black, W.C. (1998). Multivariate data analysis ( ${ }^{\text {th }}$ etn). Prentice Hall International: UK.

Kadir, Suzaina. (2009). Emerging trends in Islamic education in Indonesia, $3^{\text {rd }}$ Redisigning Pedagogy International Conference. Singapura: Lee Kuan Yew School of Public Policy

Muhab, Sukro. dkk. (2010). Standar mutu Sekolah Islam Terpadu. Jaringan Sekolah Islam Terpadu

Syarifudin, Rahmat. (2009). JSIT Memberdayakan sekolah-sekolah Islam, http: $\angle /$ www.jsit-jabar.org/?mn =detail\&id $=237 \& \mathrm{kn}=$ menu, diakses pada tanggal 20 Mei 2011. 